\title{
Legal Assurance of the Land Registration Process in the Pandemic Time of Covid-19
}

\author{
Rahmat Ramadhani ${ }^{1}$, Rachmad Abduh ${ }^{2}$ \\ ${ }^{1,2}$ Universitas Muhammadiyah Sumatera Utara, Indonesia \\ rahmatramadhani@umsu.ac.id, rachmadabduh@umsu.ac.id
}

\begin{abstract}
Circular work from home for land office employees needs to be examined whether there is a change in the mechanism in legal certainty of land registration during the Covid-19 pandemic, whether the process of measuring land and signing witnesses whose land borders comply with health protocols outside the land office, especially in the field. The issues that will be studied are the implementation of the land registration process during the Covid19 pandemic and legal certainty in the implementation of the land registration process during the Covid-19 pandemic. The results show that the land registration process during the Covid-19 pandemic is still the same as before this outbreak, and regarding legal certainty, there are no specific rules regarding the obligation to comply with health protocols when undergoing the land registration process, especially in the field.
\end{abstract}

Keywords

rules, protocols, health; registration; land

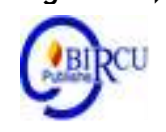

\section{Introduction}

The existence of Circular Number TU.03/569-100/IV/2020 concerning the Provisions for Implementation of Working from Home needs to be studied in relation to Covid-19 with the land registration system. Kemudian, adanya niatan untuk melakukan revisi Regulation of the Minister of Agrarian and Spatial Planning/National Land Agency (ATR/BPN) Number 11 of 2016 concerning Settlement of Land Cases, which will be conjunction with the situation of the Covid-19 pandemic outbreak because as we all know that the process of registration and settlement of land problems involves a lot of meetings or meetings. The parties concerned are in the process so it is necessary to study whether there are rules that are in line with compliance with health protocols.

The importance of reviewing the legal certainty of land registration, especially during the Covid-19 pandemic, needs more attention, because land problems are quite complex problems that need to be addressed continuously to create land administration order.

Some of the priority objectives for carrying out land registration are to maintain orderly land administration to provide legal certainty and legal protection to holders of rights over a plot of land, apartment units and other registered rights, so that they can easily prove themselves as holders of the rights concerned, to provide information to interested parties, including the Government, so that they can easily obtain the data required to carry out legal actions regarding registered land parcels and apartment units.

Other conditions, especially regarding land registration, sometimes also arise from the community, such as the existence of conditions that do not rule out the existence of rural land by urban residents, and even tend to leave it, including in land management and administration. Much of the condition of rural land ownership by urban communities only serves as a commodity for profit in the form of investment, keeping land prices inclined to 
increase in the future. Another problem that arises regarding the issue of land titles is that not all land certificates issued by villages have been converted to land having confidence in their rights.

Exacerbated by the lack of knowledge about the rule of law regarding land, the implementation of policies in the land sector is felt to be decreasing positively in intensity and can no longer be seen as part of the struggle to build the prosperity of those who can guarantee legal certainty, as aspired to, but more seen as a routine activity, confusion over land related to policies that ultimately lead to legal uncertainty in the community. In the case of handling land issues, including creating legal certainty over community land ownership in the form of land title ownership, there are two interests that must be aligned, namely individual interests which often involve people on the one hand and the interests of the other party (community) must be considered.

The existing problem is related to the guarantee of legal certainty for the land registration process during the Covid-19 pandemic associated with WFH land office employees by examining whether or not the registration mechanisms and procedures have changed during the Covid-19 pandemic period so that the authors will review them through a research discussion entitled "Legal Assurance of the Land Registration Process in the Pandemic Time of Covid-19".

\section{Research Methods}

Legal research is a process to find legal rules, legal principles, and legal doctrines in order to answer legal issues faced. The type of research used in this paper is library research, namely research using written documents as data, and the data sources used in this study include primary legal materials, secondary legal materials and tertiary materials. Primary legal materials are legal materials that are binding or that make people lawabiding, including legal products that are subject to study and legal products as tools of criticism. Secondary legal materials include explanations of primary legal materials in the form of expert doctrines found in books, journals, and on websites..

\section{Discussion}

\subsection{Provisions for the Implementation of the Land Registration Process during the Covid-19 Pandemic}

The constitution clearly states that Indonesia is a constitutional state which guarantees and protects the rights of citizens, such as the right of citizens to obtain and enjoy proper property rights. The shift in the pattern of relations between landowners and land has occurred as an effect of changes that arise in the development and engineering processes that occur in the community. Land registration, as an execution of Article 19 of the UUPA, which in essence is one of the government's efforts to guarantee legal certainty for land owners.

Mhd. Yamin Lubis and Abd Rahim Lubis in Harris Yonatan Parmahan Sibuea, stated that the authority of the Government to regulate the land sector so that it grows and is rooted in Article 33 paragraph (3) of the 1945 Constitution which in essence emphasizes that the earth, water and natural resources contained therein are controlled. by the State to be used for the people to prosper. Then the UUPA and spread to various organic regulations in the form of Government Regulations, Presidential Decrees, Presidential Decrees and Regulations issued by heads of technical institutions in the land sector. 
Analyzing the condition of Covid-19, which can be drawn from a red thread related to land registration during the Covid-19 pandemic, citing the hypothesis stated by De La Tour in Catharina, that COVID-19 occurs due to loss of natural balance, as a result of human exploitation of nature. The impact of this epidemic has damaged various regulations ranging from social, health and economy to almost most countries in the world, including Indonesia. Then, Andersen in Catharina stated that currently the world is facing an epidemic of coronavirus infection (COVID-19).

The epidemic that began in China at the end of 2019 has rapidly expanded to various parts of the world and cases of cases have been reported worldwide. There are several opinions regarding the causes of the COVID-19 pandemic. The source of the cases of COVID-19 transmission, according to the researchers, initially focused on raccoons and crickets as the main sources of infection. However, from the results of the study only samples isolated from ferrets in the food market in Wuhan, Hubei Province, China as the source city of the spread showed positive results that civet palms might be a secondary host for virus detection.

Then, Rhinolophus bats were also found to have anti-SARS-CoV antibodies which indicate bats as the source of viral replication. The scientific journal of natural medicine states that in the midst of a health emergency it makes perfect sense for people to ask about the origin of this pandemic problem. Understanding in detail how animal viruses jump over species barriers and infect humans can help in the prevention of future events like this. Conversely, if an adaptive process occurs in humans, then it is not possible without the same set of mutations. Ultimately there is no evidence to suggest that SARS-CoV-2 was a virus that was deliberately manipulated. The results of this study indicate that there is no role for humans in the emergence of viruses through genetic engineering. The international environmental organization that Greenpeace calls Covid-19 has indeed had a negative impact on trade and the economy.

In improving services in land sector that provide certainty of rights, the government has made a policy to accelerate land certificates. This policy is intended to enable any weaker-class society to have land title certificates at a lower cost, to provide legal certainty to land rights holders. Land registration is one of the activities organized by the government in the land field with subsidies in the field of land registration specifically, in the form of mass for certificates to help the weak economic class. Land registration is a national policy that intends to provide legal certainty for land rights holders to enhance or support the implementation of land reform and resolve disputes at a low cost overall.

Apart from empowering organizations and human resources. The implementation of this land registration is an effort by the government to provide stimulation and participation to land rights holders to implement their land certificates and try to help solve strategic land disputes by providing facilities and facilities and empowerment of organizations and Human Resources. Land registration is an effort to achieve a land legal order which aims to own each land by having proof of ownership in the form of a certificate, so that the land has legal certainty and strong rights. This is one proof that the law of land law has been implemented properly then with land certificates, it is hoped that land disputes can be avoided and also that the government has regular archives which aim to improve the quality of services to the community quickly, easily and cheaply, which are expected to bring benefits to the community, especially the weak economy class and also for the regular use of land.

In general, land area has a direct effect on production, if land area increases, it will automatically increase production (Hasibuan et al, 2020). According to Isnaini et al (2020) land disputes and conflicts are complex and multidimensional problems. Therefore, efforts 
to prevent, handle and resolve must take into account various aspects, both legal and nonlegal. Often the handling and resolution of land disputes and conflicts is faced with dilemmas between different interests that are equally important.

Land registration is an administrative process carried out by the Land Office in collecting and processing physical and juridical data as well as presenting existing land rights fields and apartment property rights by issuing proof of rights that serve as strong evidence. The purpose of registration is to ensure legal certainty about the object (land), the status of their rights and the certainty of the subject (right holder). Land as one of the agrarian sources has a very important role in human life and life. Therefore, land must be utilized and managed to provide great benefits for the prosperity and welfare of the community. Likewise for Indonesia, this land is a gift from Allah SWT and is a national treasure, so it must be cultivated and managed to provide maximum benefits for the prosperity and welfare of the people, nation and state of Indonesia.

Sumardjono stated that from the beginning the philosophical foundation was not given to individuals. Indonesian philosophy in the concept of the relationship between humans and land places the individual and society as an inseparable unity (duality). This means that the fulfillment of one's needs for land is set forth in the framework of the needs of the whole community, so that the conjunction is not merely individualism, but rather a collective with a fixed place of giving and respecting community rights. individual. The land has social value. Human need for land is absolute, but ownership is not absolute, because it still pays attention to interests and needs more land, namely other humans.

Land registration as mandated by Government Regulation No. 24 of 1997 concerning Land Registration. Thereby orderly, complete land registration which provides legal certainty regarding land rights throughout the territory of the Republic of Indonesia. Equality of ownership of land rights is a form of law enforcement mandated by Article 33 paragraph 3 of the 1945 Constitution which essentially emphasizes and highlights that land and waters, as well as natural wealth in them, must be controlled by the state in order to be exploited for the greatest benefit of the people. This mandate was followed by the issuance of Law no. 5 of 1960 concerning the Basic Agrarian Law, which stipulates that the state holds the right and authority to regulate and implement the appropriation, utilization, reservation and cultivation of the earth, water and air space.

This regulatory and administrative authority is exercised through the land registration process. Land registration aims to provide legal certainty and legal protection to holders of land rights. It is believed that managing land rights can reduce land conflicts. Land conflicts are a constant problem, and are an actual problem from time to time. Various land conflicts arise due to various factors such as the unequal distribution of agrarian resource use, expansion by a certain group of people, and population density. In conclusion, land conflicts are closely related to speedy and fair land registration.

In using land, land owners must pay attention to the interests of others and not harm others. The addition of land is a social value, that land rights are not absolute, it also has economic value that can be managed and processed by the owner / holder so that it provides benefits to the owner/holder. However, in its development, now this land has become a commodity tool. The State as the supreme organization of power in an area which is the territory of the Republic of Indonesia is obliged to regulate the allocation, use, utilization and maintenance for the welfare and prosperity of its people. Indonesia, where most of its people depend on their lives and livelihoods in agriculture, so that here the land has extraordinary dominance as the main necessity for national life. The policy on the use of agrarian resources including land in the Constitution of the Republic of Indonesia is mandated in Article 33 Paragraph (3) of the 1945 Constitution of the Republic of Indonesia 
which mandates that the land, water and natural resources contained therein are controlled by the State and used generally for the prosperity of the people.

The model of the land registration system used in Indonesia can be seen from the applicable legal provisions Government Regulation No. 10 of 1961 in conjunction with Government Regulation no. 24 of 1997, referring to official land ownership documents against legal provisions in the form of certificates of their rights, can approve the land registration system in Indonesia based on a registration system with a positive system, can be proven by the unique character or character of the state-owned land system, with all The set of procedures and relationships stipulated in the rule of law in the land registration system is the dominant model of positive publicity.

The negative publicity character affiliation approved in the jurisdiction of the Supreme Court of the Republic of Indonesia (MA RI), which explicitly regulates it. The state does not guarantee the justification of the data presented. Even though they have registered, the rights owner tries to prove that he is the real rights holder. Land registration must be sought, it is necessary to issue data that actually corresponds to the book and registration of land maps. In order not to be proven, the data presented in the books and maps of land registration must be accepted in day-to-day legal proceedings, as well as in litigation in court. Likewise, the data contained in the title certificate, all data such as those on the land and map registration books. In a positive system, data is guaranteed. Complete land registration is the activity of registering land for the first time simultaneously for all land registrations throughout the territory of the Republic of Indonesia.

Basically, land registration is a land certification project for the community, some of which also receive financial support or government allowances through the APBN which is borne by BPN. Land titling through land registration provides many advantages over selfcertification. These advantages include, among other things, subsidies from the government, so that people who make applications for land certificates have the cost and speed of the process of issuing certificates of certificates according to the time specified.

The active role of legal land registration aims to perpetuate a person's future rights. So, once the land is registered under his name, the validity of the name guarantee law in the certificate is no longer valid. Simpson's comment on the registration of such a part of land is not merely about realizing the protection of land ownership in the direction of legal certainty. Even landowners will get the perfection of their rights, because of things from feeling safe in having land rights (security), better understanding what and how is expected from the registration (simplicity), guarantee the accuracy of the system implemented (accuracy), easy to implement, at a cost that is affordable to all those wishing to register land, and the power to reach into the future can be realized especially at the future price of land. Records of continuous land registration will be kept at the land office.

Information about the physical land to be maintained in the form of a land book. So a land certificate (proof of rights) is given to entitled land, so every activity of the land for the benefit of the owner is actually guaranteed by law. Even if there will be a transfer of their rights, they will be clearly recorded in the land book, and the track record is maintained so that the interests of the land are above the position of the person entitled to their rights. All content / nature of rights that can be pledged or transferred, the fact of the realization of the legal certainty that is applied is the main issue and the law for now. Even the objective land registration as stated in Article 19 of the UUPA (Law No. 5/1960) further enhances its position to provide the best juridical and technical guarantees in terms of certainty of physical boundaries. Land registration activities as referred to in Article 19 of the UUPA, which only includes measurement and recording of land, Provision of proof of rights that are valid as strong evidence, Registration of land rights and transfer of these 
rights, historical ownership of land, not the establishment of a lot of legal certainty. dominated by various factors.

Circular Letter Number TU.03/569-100/IV/2020 concerning Provisions for the Implementation of Work from Home issued by the Minister of ATR/Head of BPN on April 7,2020 , is a relatively long process, besides that until now there are no regulations. specifically regarding the implementation of the land registration process that is linked to the health protocol from the government, especially regarding the land measurement process to compliance to avoid Covid-19 from being equivalent in the field (outside the land office).

\subsection{Legal Certainty in Implementing the Land Registration Process during the Covid- 19 Pandemic}

As a rule of law, the state concept makes Pancasila the basis of the concept and basis of legal policies for a strategy of legal protection for holders of land rights and access to natural resources. The theory of rule of law is one of the consequences of choosing state principles based on law as implied in the soul or philosophy of the Indonesian Nation (Five Principles of Pancasila) and the 1945 Constitution regarding the objectives of the Indonesian rule of law. Land registration procedures are very important, because this factor is a supporter of the implementation of sustainable development and the development carried out is a conscious effort made by the community to achieve a better life. That which can create a very complex problem in land registration procedures, is the guarantee of legal certainty. Land registration comes from the word Cadastre (Dutch Cadaster), the technical term for a record, which denotes the area, value and ownership (or other basis of rights) for a plot of land.

In a strict sense, Cadastre is a record of land, the value of land and rights holders and for tax purposes. Land registration aims to provide legal certainty known as cadastral receipts. Legal certainty is guaranteed to be realized in land registration, including legal certainty regarding the status of land rights, certainty of legal subjects, and certainty of legal objects. This land registration produces a certificate as proof of his rights. The opposite of land registration that fills in the cadastre is cadastral fiscal, which is land registration that aims to determine who is required to pay taxes on land.

Using Gustav Radbruch's concept of legal certainty, the registered land parcels will be protected from arbitrariness. The arbitrariness of certain parties acting in bad faith to recognize other people's land ownership. Meanwhile Prof. Dr. Sudikno Mertokusumo related to legal certainty stated that without a legal rule it would cause unrest which is defined as the start of a land dispute which is very detrimental to the parties to the dispute.

Legal certainty has several benefits, including Advancing the national economy, because land title certificates can be used as collateral to obtain bank credit, Preserving the environment, because of the definite relationship between rights holders with the aim of motivating right holders to do things related to environmental preservation, Increase State revenues, because land registration allows the administration of dismantling the transfer of rights and which allows revenue from customs in terms of transfer of names, Protects the interests of the people, especially those who are economically weak, because if land rights holders are excluded for certain purposes, rights holders will receive reasonable compensation, Prevent or reduce land disputes. Spatial planning support for development. Furthermore, the importance of land registration for the Government is information to the Government so that it can easily obtain data on land areas that have been registered. This information is related to the amount of tax for each parcel of land including the buildings on it, the implementation of orderly land administration. 
Referring to the rule of law, the certificate must be understood as a certificate which is a product of an authorized government institution so that proof of land ownership rights is less likely to experience problems, especially disputes. However, as explained in Article 32 paragraph (1), PP. 24 of 1997 a certificate is a strong proof because it cannot be proven otherwise the physical data and juridical data contained therein are accepted as correct data. It can be concluded that the certificate as a product of a government agency may be incorrect (regardless of the cause), thereby reducing the sense of legal certainty of the certificate itself. Adrian Sutedi in Indri quoted Jan Michiel Otto's opinion on legal certainty, that in order to create legal certainty, it must meet the following requirements, namely that there must be clear and consistent legal rules, government agencies implement legal rules consistently, submit and object to it, people adjust their behavior accordingly. rule of law, judges are independent, impartial and must apply consistent and obedient legal rules when resolving legal disputes, court decisions are implemented in a concrete manner.

Affirmation of the application of the principle of horizontal separation, apart from what has been mandated by the Basic Agrarian Law, can be seen in Law Number 4 of 1996 concerning Mortgage Rights (UUHT) and Law Number 28 of 2002 concerning Buildings. The UUHT regulates that mortgage rights can also be imposed on land rights including buildings, plants and works that already exist or will have one unit with land, and which are property holders of land rights. Kamelo in Ramadhani explains that the right to use for the construction of any building or business that stands on a Hak Milik is appropriately given under an agreement with a mortgage holder, as distinguished from the right to use on state land which is the object of proper ownership rights.

This means that land certificates also allow for safeguarding many issues both concerning other parties and regarding other subjects, the rights stated in the (Own) Land Certificate. Murod in Ramadhani, stated that the issue of legal uncertainty regarding legal rights certificates related to other rights subjects (other parties) could become statements of other parties regarding strategic Land packages overlapping, twice, and other disputes that contains practical social aspects and social and general aspects.

Irawan Soerodjo di Indri Harisiswati In the principle of nemo plus juris law, a person cannot take legal action beyond their rights, and the consequences of the violation are null and void (vanrechtswegenietig), which implies that legal action is considered non-existent and thus has no legal effect, and if legal action causes loss, then the injured party can ask for compensation from the parties who commit legal actions. If the rechtsverwerking institution can be used as a way to make someone a registered right holder, such as the legal owner of a plot of land protected by law, then by a series of further government regulatory deeds, which have stronger formal and material proof of departure, the latter will also be the right of the holder with stronger legal certainty. Urip Santoso, who explained Sudirman Saad's opinion, that the issuance of land certificates that are 5 years old or more based on good faith will provide legal protection for land rights holders if the cumulative conditions are fulfilled.

While barriers to state revenue are negligible and considered insignificant, land registration is not currently considered a contentious obligation for land rights. Moreover, ownership is collective ownership. So the proof of rights is not needed, so that the community is less protected. And the proof is that the land is always neglected so that the flowers are not realized properly. Psychological factors of society. Communities do not understand the significant difference between existing and non-existent land titles. In fact, the protection provided by the state for certificate holders is almost the same as for those without certificates. The reality of the absence of collateral further weakens the desire of communities to register their land. People only want to register land if there is a desire to 
use it. The downside of land registration rules to date is that many people do not know about land registration rules. Then, there are still many community complaints about the implementation of land registration. Because the implementation is sometimes not considered a strict interpretation and even different in their work.

Weakness in legal certainty over land ownership, this can be seen from the recent years that there have been many processes of land grabbing, including customary land controlled by indigenous peoples for various purposes without adequate protection. Occupation and expropriation of land rights that already have specific land title status occurs in both urban and rural areas. Subsequent land conditions resulted in various social and political disturbances. The land registration system includes the land registration procedure. As with statutory provisions, especially in the land sector, there are two land registration systems. First, with a model called deed registration or "deed registration" or land registration with a negative system or negative land registration and the second, registration right or "right registration", which is also commonly referred to as "registration with a positive system" or often called "Torrens system". The land registration system has differences and similarities, as well as advantages and disadvantages of one another. In general, differences can be seen in the form of formal documents that are used as instruments or means of proving ownership of land rights. The form of formal documents in the land registration system with a negative system is called a "deed" of ownership is a document in the land registration model with a positive system in the form of a "certificate" of rights.

The second form or the second formal form of the juridical model greatly influences the existence of the legal force of land ownership rights. Especially for the registration of land deeds, authors in Indonesia generally use the term negative registration system or negative system for mentioning the deed registration system. Basically, both positive and negative land registration systems have similarities in juridical character, namely this second model or type is another title of "registration of land rights" for the benefit of individual rights holders with the aim of providing legal certainty and legal security for land parcels held by the State. Thus the land registration system in Indonesia adopts a negative system, but the character or tendency of the systemic juridical registration system is positive. In everyday life, land certificates are often disputed, even going to court. This arises, because land has a very important function for people's lives. Legal certainty regarding the certainty of land ownership rights, to get it, the community needs to register the land to get a land title certificate, which serves as a strong evidence of ownership of land rights.

The provisions of legal certainty in the field of land, first of all, require the availability of a written law that is complete and clearly implemented in a manner consistent with the spirit and content of the provisions. Every land title that has been registered will be issued a certificate by the Land Office in each Regency / City, a certificate which is strong evidence, as long as it is not proven otherwise, the physical data and juridical data registered in the certificate must be accepted as correct data. listed in the measuring letter and the land book concerned. Land registration will be carried out as a result of the issuance of a certificate of proof of land rights which is commonly called a land certificate to the related party and will act as strong evidence of the Land Rights that he holds. Based on Government Regulation Number 24 of 1997 concerning Land Registration, the provisions of Article 32 paragraph (2), In cases in the field, land has been legally issued in the name of a person or legal entity.

Land registration is carried out on the basis of simple, safe, affordable, up-to-date and open principles. In line with the principles contained in Land Registration, the 
objectives to be achieved from the existence of such land registration will be further regulated in Article 3 PP No. 24 of 1997, states that the land aims to provide legal certainty and protection for holders of rights over land, apartments and other registered rights so that they can easily prove themselves as holders of the rights concerned. Then, to provide information to interested parties, including the Government, to easily obtain the data needed to carry out legal action regarding registered land areas. And also, for the implementation of an orderly land administration. Furthermore, AP Parlindungan said that by issuing a certificate of land rights, the owner was given legal certainty and protection from the law. Sometimes this information means that the Land Office as an office on the front lines has to maintain the necessary information, both for the government itself so that it can plan for the country's development and also for the people themselves. Important information to be able to decide what is needed for land, namely physical data that is open to the public which can be given what information is needed on an existing plot of land / building. Therefore, it is necessary to organize land administration as something normal. So the most important purpose of land registration is to provide legal protection to the owner.

The government can revoke land rights by providing compensation according to the method prescribed by law, if efforts made through deliberation fail to produce results. The right to revoke or release the right of the land owner must be done by releasing the right to land. Legal certainty in the implementation of the land registration process during the Covid-19 pandemic is less prominent in terms of detailed rules and in particular, because there are no specific rules governing land registration during the Covid-19 pandemic, and still using rules in a state without an outbreak.

\section{Conclusion}

The land registration process during the Covid-19 pandemic is still appropriate and refers to the LoGA and Government Regulations on Land Registration, but the implication of Circular Number TU.03/569-100/IV/2020 Concerning the Provisions for Implementing Work from Home issued by the Minister of ATR/Head of BPN on April 7, 2020, is a relatively long process, besides that until now there are no specific rules regarding the implementation of the land registration process which is linked to the health protocol from the government, especially regarding the process of measuring land to compliance to avoid covid- 19 of their equivalent in the field (outside the land office).

Legal certainty regarding land registration in general has been regulated, but there are no specific rules regarding complying with health protocols in the field that are part of the land registration process.

\section{References}

A. P. Parlindungan, (1993). Komentar Undang-Undang Pokok Agraria, Bandung: Mandar Maju,.

Ana Silviana, (2012). Kajian Tentang Kesadaran Hukum Masyarakat dalam Melaksanakan Pendaftaran Tanah, Pandecta, Vol. 7, No. 1, Januari 2012.

Boedi Harsono, (1997). Hukum Agraria Indonesia: Sejarah Pembentukkan UndangUndang Pokok Agraria, Isi Dan Pelaksanaannya, Jakarta: Djambatan.

Catharina Dewi Wulansari, (2020). Upaya Meningkatkan Peran Masyarakat Adat Dalam Menjaga Keseimbangan Alam Di Tengah Pandemi Covid 19 Melalui Community Based Nature Management, Bunga Rampai Asosiasi Pengajar Hukum Adat (APHA): 
Peranan Masyarakat Hukum Adat Dalam Menjaga Keseimbangan Alam Ditengah Pandemi Covid 19.

Desy Dwi Nurhayati Hartanti, Gunarto, Amin Purnawan, Development of The Law of Complete Systematic Land Registration (PTSL) and Effect of Conduct Valuesof Land Based On Dignify Justice In The District of Kendal, Central Java, Sultan Agung Notary Law Review, Vol. 1, Issue 1, May 2019.

Harris Yonatan Parmahan Sibuea, Arti Penting Pendaftaran Tanah Untuk Pertama Kali, Negara Hukum, Vol. 2, No. 2, November 2011, hlm. 287-306.

Hasibuan, A.S., et al, (2020). The Analysis of the Effect of Determinant Factors of Palm Oil Plantation Sector on Agricultural Sector Growth in North Sumatera. Budapest International Research and Critics Institute-Journal (BIRCI-Journal). P. 1083-1094.

Indri Hadisiswati, Kepastian Hukum Dan Perlindungan Hukum Hak Atas Tanah, Ahkam, Vol. 2, No. 1, Juli 2014.

Isnaini, et al. (2020). The Models of North Sumatra Provincial Government Policy in Resolving the Ex-Hgu Land Conflicts of PTPN II Plantations in Deli Serdang Regency. Budapest International Research and Critics Institute-Journal (BIRCIJournal). P. 1206-1215.

Lestari, Kurnia Warman, Beatrix Benni, Release of Land Rights for Development through Notarial Deed in Padang City Widia, International Journal of Multicultural and Multireligious Understanding (IJMMU), Vol. 6, No. 5, October 2019.

Moh. Akli A. Suong, Sistem Pendaftaran Tanah Menurut Hukum Positif Nasional, Jurnal Media Hukum, Vol. 1, No. 1, Februari 2013.

Muhammad Yamin, Problematika Mewujudkan Jaminan Kepastian Hukum Atas Tanah Dalam Pendaftaran Tanah, Pidato Pengukuhan Jabatan Guru Besar Tetap dalam Bidang Ilmu Hukum Agraria pada Fakultas Hukum, diucapkan di hadapan Rapat Terbuka Universitas Sumatera Utara Gelanggang Mahasiswa, Kampus USU, 2 September 2006, Universitas Sumatera Utara, Medan, 2006.

Peter Mahmud Marzuki, Penelitian Hukum, Jakarta: Kencana Prenada Media Group, 2005.

Ramadhani, Rahmat, Jaminan Kepastian Hukum Yang Terkandung Dalam Sertipikat Hak Atas Tanah. De Lega Lata Jurnal Ilmu Hukum Fakultas Hukum Umsu. Vol. 2, No. 1, Tahun 2017.

Ramadhani, Rahmat. Konstruksi Hukum Kepemilikan Bangunan Di Atas Tanah Hak Milik Orang Lain Berdasarkan Perjanjian Build Operate And Transfer (BOT), Jurnal EduTech, Vol. 4 No.1 Maret 2018.

Ricco Survival Yubaidi, (2020). The Role Of Land Deed Official Regarding Legal Certainty Of Complete Systematic Land Registration, Jurnal Hukum dan Peradilan, Vol. 9, No. 1.

Richard Richard, (2018). Regional Regulation Of Land Registration In Indonesia Related To Government Regulation No. 24 Of 1997 Concerning Land Registration, International Journal of Civil Engineering and Technology (IJCIET), Vol. 9, Issue 10, October 2018.

Rina Yulianti, (2020). Revitalisasi Kearifan Lokal Masyarakat Hukum Adat Di Pesisir Dan Pulau-Pulau Kecil Dalam Menjaga Keseimbangan Alam Ditengah Pandemi Covid 19, Bunga Rampai Asosiasi Pengajar Hukum Adat (APHA) : Peranan Masyarakat Hukum Adat Dalam Menjaga Keseimbangan Alam Ditengah Pandemi Covid 19.

Shinta Novi Wardhani, Rusdianto Sesung, Kekuatan Hukum Sertifikat Hak Atas Tanah Dikaitkan Dengan Kepastian Hukum Dalam Pendaftaran Tanah, Al-Qānūn Jurnal Pemikiran dan Pembaharuan Hukum Islam, Vol. 21, No. 1, Juni 2018. 
Sri Ahyani, (2017).Land Registration As A Legal Construction Of Law In Order To Facing Asean Economic Communities, International Journal of Nusantara Islam, Vol. 06, No. 02.

Suharni, Legal Certainty Of Land Registration Obtained Based On Division Of CoProperty Rights Over Inheritance As A Basic Of Trading Rights Without Other Heirs Approval, International Journal of Business, Economics and Law, Vol. 14, Issue 4, December 2018.

Supriyadi, (2007). Hukum Agraria, Jakarta: Sinar Grafika.

Urip Santoso, (2010). Pendaftaran dan Peralihan Hak atas Tanah, Jakarta: Kencana. 